\title{
MIR181A1 Pre-miRNA
}

National Cancer Institute

\section{Source}

National Cancer Institute. MIR181A1 Pre-miRNA. NCI Thesaurus. Code C82782.

MIR181A1 pre-miRNA is an oligoribonucleotide that is encoded by the human MIR181A1 gene and has a role in the regulation of gene expression. 